ing on her back failed to budge her. She may have been covering young at the time.

We did not again visit the nest till mid-September when we found it vacated. Some earth had fallen into it from above. I can remember on a former occasion seeing a young bird that had perhaps been crowded out by earth falling into the nest being sheltered and cared for in a suitable shelter of rock at the bottom of the cliff.

As I have intimated, Mr. Roy and myself were unable to see the top of this nest at close quarters but the remains of rabbits were liberally strewn around the top of the hill. This nesit has been used regularly for the past five years. Other nests I have observed close-up had many remains of rabbits, gophers, weasels and carrion and had feathers of grouse and partridge. Eagles seem to have voracious appetiites.

EDITOR'S NOTE: Because nesting records for the Golden Eagle in Saskatchewan are rare, Mr. Santy and other readers will be interested in a histcrical account of the eagle nesting in northern Saskatchewan to be found in the Annual Report Geological Survey of Canada VIII (new series), 1895, part D, published 1896. On his 1892 expedition, Joseph Burr Tyrrell had the following note for August 11: "the river (Stone River, now called the Fond du Lac River) turns sharply from the south, arcund a sandstone hill on the east side of which is a beautiful cliff seventy feet high, where a pair of golden eagles (Aquila chrysaetos) have had a nest for a number of years." In his introductory remarks, Tyrrell previously stated that "a large golden eagle was shot beside its nest on a rocky cliff overlocking the Stone River."

\title{
THE WASCANA CANADA GOOSE PROJECT, 1957-1958
}

\section{By Fred G. Bard and Fred W. Lahrman, \\ Siaskatchewan Museum of Natural History}

The unusually fine weather in the winter of 1957-58 contributed to last spring's nesting success in the Wascana Waterfowl Park Goose project. Ninety-four Canada Geese came through the winter. Later the 1957 young left to "summer" away from the sanctuary. These same young returned a ferv days before the shocting season opened.

Nest building began the first week of April and the first young hatched on May 6. Nineteen pairs of geese brought off 46 young (from 11 nests). Two settings were donated to assist Abernethy and Eston parks. Six nests were destroyed by predators or through interference with the nesting birds. Sitting hens were used only when a goose deserted her nest. The young hatched by hens were introduced into the wild two days later.

Elevated nestis like those first used in Colorado experiments ware built in an attempt to overccme some of our losses. Of seven elevated nests made only one was used. It would appear that we placed them too close together and that they were much too high. We shall re-locate them this winter.

During the summer three adults died from flying into power lines or from unknown causes. A recent count showed 134 geese still in the park. We expected the birds to migrate this fall as frequent visits were made to stubble areas outside of the sanctuary, but they are still here (Oct. 31) and appear to be going to remain in the area. So farthe sportsmen in the Regina area have recognized the park geese and refrained from shooting them.

Occasionally other geese wander into the sanctuary. Late this fall a White-fronted Goose (Anser albifrons) lit among the Canada Geese and gave us an opportunity to observe it at close range.

A meeting of the Waterfowl Plark committee will be held in November to hear a park progress report and to discuss utilization, development, and future park plans.

Perhaps the most sericus problem cisnfronting our park is that of fluctuating water levels and marginal shoreline changes due to development through city expiansicn. Every growing city has similar problems, but Regina's is unique. The Waterfowl Park is an important part of our parks system and our needs musit be presented to those responsible for town planning in order to familiarize the various departments with cur needs.

In the Waterfowl Park this year it wras encouraging to note that after gravel was placed on Tern Island (to help build up and maintain this area) Common Terns returned to nest here. It's a small beginning but very encouraging. 